\title{
Challenges \& Opportunities for Venture Capital Industry in Pakistan
}

\author{
Mukesh Kumar and Faysal Abdullah \\ SZABIST \\ Karachi, Pakistan
}

\begin{abstract}
Venture capital has played an important role in the development of many sectors of different economies. It is the key driver in innovation, new firm creation, rapid growth of businesses, in promoting entrepreneurship, enhancing competition and job creation. Currently, venture capital industry of Pakistan is in its infancy and facing issues such as risk adverse attitude of entrepreneurs, family owned business mindset, and limited support from the government and listing regulations for SMEs. However, economic development in last 5-6 years has been able to influence many sectors of Pakistan's economy. This is an ideal time for the venture capital industry to take off, provided both government and industry play their role and make efforts in the right direction. The author has studied the local venture capital industry, its issues, challenges, opportunities and recommendations to realize the potential.
\end{abstract}

Keywords: Venture capital, entrepreneur, economic development

\section{INTRODUCTION}

Venture capital is the key driver in innovation, new firms' creation, rapid growth of businesses; it helps promote entrepreneurship, enhances competition and job creation. Global successful firms like Intel, Oracle, Skype, Federal Express, Cisco, AMD and 3Com were first funded by venture capital firms [1]. In USA, venture capital backed companies are employing more than 10 million people in sectors ranging from telecom, technology, retail to financial services; and generated annual revenue of US \$ 2.1 trillion in 2005 [2]. In India, venture capital has contributed in developing IT and related services clusters in Bangalore and Pune. Venture capital has significantly played role in development of software, semiconductors and biopharmaceutical sectors in Israel. The success of electronics industry in Taiwan is linked with venture capitalists. In the changing global scenario, strong venture capital in any economy is critical to exploit the services and medium to high-tech manufacturing sector.

Pakistan, with a GDP of US \$ 141 billion in 20062007 has emerged as one of the fastest-growing emerging market economies with above $6 \%$ growth rate during the last five years. This impressive turnaround of Pakistan's economy has been achieved due to fiscal discipline, economic reforms, growth oriented policies, government transparency, and accountability in the last six years. Banking sector of Pakistan has seen 30-40 percent growth in last 4 years, which has not only attracted local investors but, also one, saw the takeover of Pakistani banks by foreign banks. Standard Chartered has acquired Union Bank; ABN Amro has purchased Prime Commercial Bank, NIB Bank by Singapore Group and investments Middle East investors in banking sector. According to recent State Bank report, consumer lending is still increasing even when average consumer lending rate is $18 \%$, which indicates that growth in banking sector will continue.

Government is also focusing on SMEs which are almost 99 percent of 3.4 million business establishments [3] in Pakistan and is spending huge amount on the development of SMEs sector; particularly dairy, marble and granite, gems and jewelry, wooden furniture, sports goods, leather and light engineering products.

Besides the above-mentioned developments in the country, Pakistan is also facing some critical issues. The country is the front line ally of the US in the war against terror, which has worsened the security situation in many areas, particularly NWFP and FATA. The most dangerous outcome is increase in the suicidal attacks on government officials and law enforcement agencies. Baluchistan is also facing law and order issues and this puts a major question mark on the development of Gawadar port. Not to forget, the judiciary crisis had already caused much heartache to the government. On the political front, the upcoming general elections, by the end of this year, may eventually bring about changes in the politico-economic situation within the country. Rising inflation rates (SPI in 2004-05 was 11.55 and CPI was 9.28, and in 2005-06 it remained 7.02 and 7.92) [4] forced SBP/Government to intervene and introduce strict monitory policy, which not only raised the interest rates but also affected growth in private sector lending.

Power supply shortage is hurting the industrial production and commercial activities. Shortage in supply of natural gas also results in closure of industrial units in many areas of Pakistan in winter season. Added to that, the industrial estates also lack proper roads, water supply and sanitation facilities. Hence, Pakistan needs to modernize its infrastructure, improve tax collection and normalize relations with its neighbors to fully realize it's potential.

\section{ENTREPRENEURSHIP IN PAKISTAN}

The growth in the economy of Pakistan in the last few years has created a new generation of entrepreneurs. There are a few communities in the country, which are very successful in businesses; these include Memon, Agha Khanis, and Chinioti Sheikh etc. Besides these, there are 
also big industrial/business groups like Mansha Group, Chenab Textile, Arif Habib, Dawood Group, AKD Group, Dewan and others to name a few. However, the younger generations who have taken over these businesses and who have received best education from the local and foreign educational institutes have been able to positively affect their businesses by changing the mindset and bringing latest business strategies. Currently, services sector contribute 52\% to the economy of Pakistan. Banking, leasing, insurance, health services, education, telecom, IT, tourism and allied services, courier/cargo services, travel operators, printing, consultancy and other sectors have contributed in the growth of services sector. This growth has resulted in new class of entrepreneurs because many of these business opportunities did not exist just a decade back.

We have also seen increasing number of people in middle class in last 5-6 years, due to industrial growth and services sector expansion. This group not only includes salaried people who are employed in the industrial and services sector, but also the entrepreneurs who benefited in last decade due to the consistent economic policies of the government. There are also many other reasons for opting entrepreneurship by more and more people like friendly government organizations to guide them compared with past, comparatively easy and quick access to finance, underpaid employment and unemployment, decreasing government regulations, and opening of new business opportunities etc. Increasing number of companies registered with SECP in last few years also supports this argument.

Table 1: Annual company registration number

\begin{tabular}{|c|c|}
\hline Year & Companies registered \\
\hline 1999 & 942 \\
\hline 2000 & 1,048 \\
\hline 2001 & 1,120 \\
\hline 2002 & 1,373 \\
\hline 2003 & 1,736 \\
\hline 2004 & 2,583 \\
\hline 2005 & 4,234 \\
\hline 2006 & 5,539 \\
\hline
\end{tabular}

Source: SECP

\section{SOURCE OF FUNDING FOR PRIVATE SECTOR IN PAKISTAN}

One of the most important supporting elements for the economic development of any country is the easy access to finance. There have been many channels and modes of finance available for private sector in all sectors. In Pakistan, the main options of finance for starting or expanding their business by private sector have been:

- Personal equity: Inherited wealth or savings made during career is used to start business
- $\quad$ Family and friends equity: Family and friends provide funding to start and expand the business on interest free basis and/or profit sharing basis

- $\quad$ Equity (stock markets): In this option, businesses are listed on stock exchange and profit/loss is shared with investors. But due to paid-up capital, compliance and other requirement, this only suits large companies

- Bank loans: Banks provide project financing, term loans, working capital finance etc on basis of client history, soundness of business and collateral requirement

- Angel investors: Investors providing capital for start-up or expansion and looking for high returns

- Other sources: Credit cards, private credit lenders etc

\section{Banking sector in Pakistan}

Banks have been major source of finance for private sector businesses in Pakistan. Before 1990, the Government owned most of the banks in Pakistan. There were also few development financial institutions to support the agriculture (ADBP), industry (National Development Finance Corporation, Industrial Development Bank of Pakistan) and small business (Small Business Finance Corporation and others). Most of the appointments and loans were being made on political basis, unions were very strong and banks were over staffed. There were huge non-performing/default loans. Although privatization started in early 1990s and banking reforms were also initiated in mid 1990s, but true banking reforms were initiated by Mr. Shaukat Aziz (the PM of Pakistan and Finance Minister at that time) in late 1990s and early years of 2000 millennium. On the one side, public banks were being privatized while on the other side SBP took major steps to support the banking system in Pakistan. Since last 4-5 years, banks have seen tremendous growth (profits after tax of all banks have increased from 2.9 billion rupees in 2001 to 84.1 billion rupees in 2006) [5] and they have also made huge lending to the private sector. Access to lending is easy for corporations and big and medium sized companies due to their sound business history, book keeping system, documented business and availability of HR to prepare the business plan, feasibility study reports, accounting statements and other documentation. But $99 \%$ of 3.4 million business establishments are SMEs. Most of these SMEs do not keep proper accounting books, do not use banking channel for business transactions, not registered with tax authorities, do not have capability to prepare the documents required by banks; and most important they do not have collateral to pledge with banks. Due to these issues, it is believed that, banks are hesitant in financing small and medium enterprises (SMEs). Getting finance is more difficult for entrepreneurs who want to start new business particularly those businesses, which are not traditional and have different business model. 


\section{Angle investors}

There are few groups, which are very active in financing (partially to full project financing) for ventures in different sectors. Few groups like KASB, Packages, Arif Habib Group, Jehangir Siddiqui Group, AKD Group and others are actively investing in different ventures [6]. Some of the above mentioned groups have also invested in venture capital companies. There are certainly advantages of these angles, like investment source is readily available which is usually unavailable in normal conditions. These groups have a presence in the market since many decades and they have an in-depth knowledge of the business environment and business mechanism in Pakistan, and due to their name and credibility other investors also willingly invest in such projects. At the same time, there are a few disadvantages, like there are limited companies/groups who invest in such type of ventures. Persons and companies looking for such investment are not aware of such companies/groups/ business angles; and if few people know about such investment companies, they have problems in getting an access to such companies. Core concept of VC companies is not only to provide funding but also to provide management services (marketing, management etc), but here that element is missing. They do not look for small size projects. They are very dominant partners and such situation creates frustration and de-motivation among the people/companies who get funding from this source.

\section{VENTURE CAPITAL INDUSTRY IN PAKISTAN}

Around the world, Venture Capital has played a major role in the success of enterprises and specially SMEs. The significant and strategic role of Venture Capital industry as a potential source of financing is growing in both developed and developing countries. There is usually a direct correlation between the amount of Venture Capital available to a company and its pace of growth. Similarly, the greater the amount of Venture Capital available in the country, the quicker the technology driven sectors can grow.

Venture Capital funding is different from traditional sources of financing. Venture capitalists finance innovative ideas, which have potential for high growth but inherent uncertainties. This makes it a high-risk, high return investment. Apart from finance, venture capitalists also provide networking, management and marketing support. In the broader sense, investors and investee firms' work together closely in an enabling environment that allows entrepreneurs to focus on value creating. This blend of risk financing and hand holding of entrepreneurs by venture capitalists create an ideal environment particularly suitable for knowledge and technology based enterprises.

Venture capital has played a significant role in economic growth and wealth creation in various developed and developing countries; and is generally perceived to support scientific, technological and knowledge based ideas only. It has played a pivotal role in recent IT boom but at the same time has continued to support traditional forms of businesses as evident from the Indian example. Pakistani entrepreneurs are more inclined towards starting and investing in traditional businesses, as they are risk averse. Consequently, they start businesses with relatively low risk and low return but with sound cash flows. Currently, the venture capital/private equity industry is small. Some of the local brokerage houses such as AKD Securities, BMA Capital, AMZ Group, and Jehangir Siddiqui have set up venture capital firms. Jehangir Siddiqui has received financing from International Finance Corporation (IFC), BMA Capital from UAE's Abraaj Capital (Cupola Group), and AKD Securities from PakKuwait Investment Company. Some of these firms specialize in one sector only, for example, BMA Capital is focusing on real estate; while Jehangir Siddiqui and AMZ group are investing in IT projects.

AKD Securities and Pak-Kuwait Investment Company set up TMT Ventures Fund. Set up in 2002, it is the first fund that has been registered under SECP Rules 2001. Focusing on technology, media and telecom sectors, this fund (Rs. 250 million worth) comprises Rs. 50 million investments by AKD Securities, Rs.75 million from PakKuwait and the remaining from a consortium of institutions. TMT ventures have provided VC funding to seven projects and recently they have exited from one company i.e. RFM Loyalty (Pvt.) Limited [7]. AMZ has invested in its own U.S. based subsidiary, AMZ Access (Pvt.) Ltd, which is engaged in Business Process Outsourcing (BPO) in the U.S, focusing on medical transcription services for U.S clients. This company was established in December 2004 and still going in losses. TRG, another venture capital firm, is listed on Karachi Stock Exchange and is engaged in providing call center services to the U.S and other countries. TRG model is based on acquiring call center companies in the U.S and shifting the operations to Pakistan.

The people who were successful in running their businesses in IT and knowledge based companies became venture capitalists. This group of companies and countries prefer technology and innovation driven companies. U.S, Israel, Taiwan and European countries have followed this model; whereas, India and other developing countries focus on mix of projects i.e. technology driven as well traditional businesses.

\section{GLOBAL OVERVIEW OF VENTURE CAPITAL INDUSTRY}

\section{Indian experience}

India started exporting software in the 1970s with contract programming. Till 1980s, this form of software exports continued where only local Indian companies were contributing to the process due to the government policy. 
Indian software companies were facing a lot of issues, such as high duties on computer hardware and strict regulations on software import. But this period of restrictions created thousands of people with programming skills and/in particularly UNIX. Hence, in 1980s and 1990s, when there was high growth in Internet, the Indian IT human resource became in high demand. According to Mr. Dossani [8], from 1991 onwards, the Indian economy was opened to foreign investment. Almost immediately, the U.S. high technology firms began outsourcing development in India, leveraging local knowledge of English, lowering labor costs, and adding value without risk. Indian firms which had until then focused on hardware and software design, and on products and services for the local market, were unable to compete for the U.S. firms demand for labor. They shifted their focus to export market. Till late 1990s and early years of 2000, India was unable to stop migration of quality IT engineers and programmers to the U.S. and others countries. But the large number of top tier quality computer engineers $(60,000$ plus in late 1990s) migration did not create hurdles in the growth of Indian IT industry. In mid and late 1990s, there was also one major concern among the IT, other industry analysts and the policy makers, that Indian IT engineers and programmers were not willing to work with new companies or starting their own companies. According to Mr. Dossani, "this may reflect the financially insecure background from which Indians come, or the country's long-standing culture of bureaucratic culture”.

Mr. Som Das and Mr. Sudhir Sethi, who were working with Indian investment groups, referred to this fear in one of their presentation in a conference on “Accessing Venture Capital in India”, in 1999 at Stanford University as being " 51 percent ownership syndrome” [9]. This highlighted one major issue that entrepreneurs in India wanted to keep 51 percent ownership of business with them which created less attraction for venture capital firms. So this was one of the reasons that venture capital firms were focusing on later-stage project financing in this period. Few analysts were satisfied with this phenomenon in India as venture capital industry of Israel also went through similar experience. According to CEO Blumberg, "once the 'low hanging fruit' of late-stage firms is plucked and venture capitalists have shored up a reservoir of talent to advice start-ups, the situation changes quickly". On the positive side, Indian IT professionals in Silicon Valley, USA, started more than 600 firms during eighties and nineties. Each passing year was showing positive trends like risk taking attitude, increasing entry of young and qualified entrepreneurs and senior management people to the new businesses.

At the same time, venture capital firms in India were facing some issues particularly related to HR. Most the people working with venture capital firms came from public sector banks that had risk aversion attitude and lacking management skills.
According to the World Bank report in 1989, small and medium size companies needed funds in the form of equity not in the form of loans. The World Bank also identified that young growing companies were not able to get funding from equity markets. This process resulted in the establishment of four venture capital companies in 1990; two by state government and two by federal government. In 1996, foreign as well as local private venture companies started operations in India. According to Mr. Dossani in 1999, "The venture capital supplied to India remains small and dominated by foreign investors. Domestic pension funds, insurance firms and mutual funds are not allowed to invest in venture capital firms”.

Mr. Saurabh Srivastava, Chairman Indian Venture Capital Association, called 1995-99 as second phase of Indian venture capital industry when industry was dominated by foreign venture capital funds [10]. It was only year 2000 and onwards when industry saw successful domestic venture capital firms. This was called as third phase of Indian venture firms, by Srivastava. According to the Indian venture capital industry association in 1998, out of 719 financed companies, only 166 were late-stage financing and the rest were seed-stage and early step financing.

India also faced regulatory issues during the initial phase of venture capital industry. In India, the trust form is more tax advantageous than company form and even it allows complete tax exemption for trust and investor in a typical case. But there were some restrictions under Indian Trust Act, like loosing tax-exempt status in case of issuing convertible preference shares and voting rights was not linked with equity. Indian tax status of dividend payout was much favorable, but Indian tax code did not recognize either unrealized capital gains or losses as taxable income or loss. Capital distribution was only allowed to investors in the case of closure of firm and new firms, which might be loosing money in initial years, were not able to pass it on to the investors. Initially, when venture capital firms were allowed tax incentive, other corporate form firms started registering under venture capital firms and continued financing conventional sectors. Looking at this exploitation, tax authorities restated the law and tax incentive was restricted to sectors like software, IT, production of basic drugs, biotechnology and agriculture and linked it with few approvals. These restrictions created new bureaucratic hurdles. There was also conflict among Finance Ministry, SEBI and tax authorities.

According to Professor Ramchandran, "god to dog" phenomenon existed in Indian venture capital. Companies looking for finance treated venture capital firms like god during the borrowing process but then they treated them like dogs.

In the early years of industry, most of the exits were routed through acquisition. The reasons for not divestment of companies through IPO were poor stock 
markets and tough listing requirements of Reserve Bank of India (RBI). But this situation improved later on. In the year 2002, there were 41 exits while the year 2003, which was a good time for IPO, many companies also, took this route for exit.

According to Mr. Dossani, business could be started and bought relatively cheaply and quickly in India in 1990s. But infrastructure to support the businesses was weak compared with developed world. Software Technology Parks (STPs) was the initiative of Indian Government in collaboration with private sector to support the entrepreneurs in space provision and communication infrastructure. There was weak link between education institutes and academia and other research centers. But the 1998 IT policy was the major step by the Indian government which brought IT industry at the current level. Under this policy, government crated one billion rupee venture capital funds through Small Industries Development Bank of India (SIDBI). This policy also focused on telecom infrastructure development, simplification of regulations for IT industry and tax incentives for IT businesses; it encouraged banks to lend IT sector companies and duty free import of computer hardware and software besides other supporting initiatives.

\section{Start of venture capital in China}

The Chinese venture capital industry started in the mid-1980s when the government decided that it should develop various high-technology industries. Due to lack of experience among government officials and venture capitalists, most of the initial efforts in this industry failed. The China New Technology Start-up Investment Company, one of the well-known venture capital firms in China, went bankrupt in 1997. Fortunately, although most of the early efforts failed, there has been a steady flow of support from the government and the private sector for the development of a venture capital industry in China. After years of sluggish development, China's venture capital industry grew rapidly in 1999 and 2000. As people gradually understood and accepted the concept of knowledge economy, high-tech industries and venture capital; the venture capital industry has taken its initial form and begun its rapid development. According to industry sources, there were 120 venture capital firms and 156 incubators in China in 2000. Beijing, Shanghai and Shenzhen are emerging as the centers of the Chinese venture capital system. In first half of 2006, there were 85 deals and amount invested by venture capital was around US \$ 800 million.

\section{Taiwan experience}

Higher economic growth in 1990s and favorable government policies along with priority for education and support for small entrepreneurs contributed in success of venture capital industry in Taiwan. The initiatives taken by government, like establishing Hsinchu Science-based Industrial Park, were able to reverse brain drain Taiwanese
IT professionals working in U.S. There were 3,000 expatriates entrepreneurs who came back from USA and started their businesses in Hsinchu Industrial Park. The priority for education can be judged from the fact that by late 1990s, annually 50,000 engineers were graduating from Taiwanese institutes. Interestingly, the venture capital companies in the initial phase earned good returns due to high economic growth and better exit opportunities particularly through stock market.

Dossani writes in his report that 'Taiwan's government has been particularly successful in promoting its hardware industry through tax incentives for returning expatriates, low tariff barriers, large amounts of credit at cheap rate, good infrastructure facilities and establishment of research institutes”.

Taiwanese engineers who were working in Silicon Valley, USA, were more successful than Indians in mid 1990s due to better business environment, better infrastructure, aggressive support from government and high economic growth in Taiwan, during that period.

\section{Israeli experience}

The venture capital industry started in 1989 in Israel and within a decade the number of firms was close to 100 . Israel was successful in producing technology during the same period when India pioneered developing software and Taiwan was successful in manufacturing computer hardware. Highly educated and technology expert Russian immigrants were the main contributor in the technology boom in Israel which caused venture capital industry to establish and grow. The exit mode of acquisition by local larger IT companies was very successful but domestic stock market was not strong to support IPO exit. But this gap was filled by targeting U.S IPO market. Israel government also played a significant role in developing venture capital industry by restructuring accounting, legal and regulatory framework, encouraging and supporting technology research, marketing help to access global markets, establishing technology incubators, tax incentives and providing support services to small businesses and new entrepreneurs.

Israel established Bilateral Industrial Research and Development Foundation (BIRD) in 1977 in collaboration with U.S government, to fund joint venture between U.S and Israel firms. The success of BIRD can be judged form that fact that it has funded more than 500 companies with average funding of $\$ 1.2$ million for twelve to fifteen months duration. Israeli venture capital companies invested more than U.S \$ 1.3 billion in 2005, compared with U.S \$ 725 million. 


\section{ISSUES \& CHALLENGES FOR VENTURE CAPITAL INDUSTRY IN PAKISTAN}

\section{SWOT analysis}

\section{Strengths:}

- Better economic growth in last 6 years

- Growth and consolidation of banking sector

- Better spending on higher education

\section{Weaknesses:}

- Lack of entrepreneurship

- Shortage of skilled human resource

- Lack of innovation and R\&D among enterprises

- Limited knowledge based sectors

- Risky investment and few exit opportunities

\section{Opportunities:}

- Increase in foreign direct investment

- Young entrepreneurs willing to share the success

- Growth potential in many sectors of economy

Threats:

- Law and order situation

- Political Instability

- Country Image Perception

\section{Business and technology incubation centers}

Incubators typically give a very initial stage support to young entrepreneurs who want to develop their idea to a viable commercial proposition, which may be financed and supported by venture capitalist.

In Pakistan, National University of Science \& Technology (NUST) has established Technology Incubation Center (TIC) in Islamabad in 2004. There is need to establish many incubation centers in other universities/research centers with strong collaboration of private sector.

\section{Late return investment}

Venture capital investment is comparatively longterm investment; i.e. average success time is 4-8 years. We have seen huge investment in real estate by local as well as overseas Pakistanis and some times they also wait for few years for their required returns. But there is fear of their investment becoming zero in case of failure of VC project, which we do not see in real estate and other investments.

\section{Few opportunities for exit}

Exit is an important part of the venture investment cycle. IPO, mergers and acquisitions are main channels of exit. In Pakistan, listing of small and medium size companies on stock exchange is not viable due to initial high cost and lot of reporting requirements. There is no tax benefit for the company to list on stock exchange. According to Mr. Sohaib, companies having worth of U.S
\$ 4-5 million may be in position to be listed on local stock exchange; whereas, for offshore listing the requirement goes between U.S \$ 12-15 million dollars. Looking at these factors, listing of VC projects in Pakistan seems difficult in current scenario. Small and medium size companies prefer expansion of their own businesses instead of buying other businesses for expansion, which also results in very few mergers between SMEs. Earlier, VC companies in Pakistan were not focusing on exit strategies at the time of investing in companies. The main reason was lack of expertise for designing exit strategies and other reason was infancy stage of VC industry. But now, they have realized the significance of formulating exit strategy for success of VC Company.

\section{Lack of innovation in Pakistani enterprises}

As venture capital companies are interested in ventures having innovative ideas with potential of high returns; Pakistani educational institutes, particularly engineering institutes, lack research facilities as well as attitude. Similarly the private sector is not willing to invest in research and development. This is also visible from very few patent and copyright registrations (around 600 patents registered during 2005 and 2006 but most of these were made by multinational companies). Even after getting copyright and patents of their products, it is very difficult to stop other companies to copying the products due to weak legal framework and weaker enforcement system.

\section{No investment in VC funds by government agencies}

Government of Pakistan has initiated couple of funds i.e. Competitive Support Fund (CSF) and Business Support Fund (BSF), but these funds support only existing businesses. Besides these, there is no exclusive fund by federal or provincial government for VC. Pakistan Software Export Board (PSEB) is also making efforts to initiate 50 million dollars VC fund with other agencies for the enterprises in the area of software development and information technology. But there is need of sector specific VC funds focusing on early stage companies.

\section{Deal flow and culture of shifting businesses to their next generation}

The attitude of business people in Pakistan is having full control over business. This is the reason that people do not want to get financing from sources like venture capital, where they are required to share their business. This issue is called as deal flow, and India also faced this issue in their early stage of venture capital industry. In Pakistan, there is tendency of shifting business to their next generation. Enterprises in Pakistan do not think of selling their businesses even in the case of getting better value. So there is clash in the culture and attitude between VC companies and business community in Pakistan. 


\section{Low investment by overseas Pakistanis}

Large numbers of Pakistanis are living in USA, UK, Canada, Australia, Middle East region and other countries. A good number of these people are employed in financial and technology sectors but we could not attract them to invest in Pakistan and could not get benefit from their expertise, knowledge and market linkages.

\section{Limited knowledge based sectors in Pakistan}

Main interest of VC companies has been in knowledge-based sectors due to potential of their growth. Bio Technologies, Business Process Outsourcing (BPO), Information Technology (IT) and related services, pharmaceutical research (drug discovery), health services are few of these sectors where Pakistan has opportunity to make a lot. These sectors have big opportunities for exports and also appetite of VC funding. There is low level activity among few of these sectors but most of the work is focusing local market only. Interest of VC companies will only come to these sectors when these sectors will grow to a level when they can target export markets also.

\section{Shortage of skilled human resource and its management}

Bankers in Pakistan have expertise in evaluating the risk and worthiness of the projects, but they have no experience of supporting their clients in management and marketing areas. In other countries, VC companies have pool of experts in different function areas and these experts have also experience of running few companies. But if we look at Pakistani scenario, this element is totally missing.

\section{Legal and accounting issues}

Venture capital differs from standard forms of financing in a major way because there is much more involvement of providers of funds than is the case with other forms of lending such as bank loans. Venture capital investors are also concerned about resolving the uncertainty of cash flows. Currently, VC companies are being registered under NBFC Rules \& Regulations 2003 and SECP has also prepared draft rules for Private Equity \& Venture Capital Companies 2006. Industry players have few concerns on these issues particularly registration of foreign VC companies with SECP in case of VC investment in Pakistan and regulatory measures which reflect comparison of VC with mutual funds by SECP. Besides above, they also feel Venture Capital companies face same reporting requirement as for other companies listed on stock exchange. According to Mr. Zulifqar, there is urgent need of allowing limited partnership firms to operate venture capital firms in Pakistan [11].

\section{Lack of entrepreneurship}

There is lack of entrepreneurship culture in the society of Pakistan. Only those graduates (business, engineering and other fields) join the business whose families have any business i.e. these graduates do not start their own businesses. Generally, people start those businesses, which have high probability of success. Getting finance for new business is very difficult in Pakistan and particularly equity ratio requirement is very high. According to Mr. Nadeem Ul Haq [12], government polices have also promoted "rent-seeking” (rent-seeking is defined as a situation in which an individual or firm makes money by manipulating economic environment rather than by profit making through trade and production of wealth) investors instead of entrepreneurs. There is also shortage of Business Development Services (BDS) providers in the market who can support SMEs in the areas of HR, marketing, technical issues. Government support is also limited for new entrepreneurs.

\section{Country image perception}

Companies of U.S, European countries and other countries have more concerns on law and order issues in Pakistan, due to the international media exaggeration on such incidents in Pakistan. Besides law and order, there is also element of trust and confidence on Pakistani enterprises, due to bad business practices by few Pakistani businesses. Continuity in quality is also area where we have failed e.g. Pakistan was doing very well in medical transcription, but we could not maintain quality which resulted in closure of business for few good companies also.

\section{Restructuring and consolidation of financial sector}

Financial sector of Pakistan has seen growth in last five years and currently this sector is undergoing consolidation phase. We have seen takeovers of Pakistani banks by foreign banks and mergers among local banks. In the early phase of venture capital industry in India, banks started venture capital companies as their subsidiaries. Besides this, banks in India also invested in VC companies; but banks in Pakistan have not reached this stage. Pakistani banks have recently started investing in mutual funds and couple of banks has entered in private equity, which indicates immaturity of financial sector of Pakistan.

Indian economy was much close economy in 70s and 80s, which helped them in establishing manufacturing base. Whereas, Pakistani economy has been much open resulting in easy imports of technology and raw materials; so Pakistan could not develop solid engineering base. Strong IT skills base in India and presence of many IT professionals in USA were the early factors to attract VC companies in India. Taiwan and Israel also benefited similar phenomenon. Pakistan had comparable similar opportunity in early 90s in IT sector, but Pakistan could 
not capitalize this window. In all these countries, initially government established VC funds and in most of the cases, these were not successful; but even these funds were able to create base of the industry. Besides VC funds, these countries also invested in R\&D and innovation initiatives, particularly Taiwan was successful in brain drain of engineers from USA by establishing Industrial Park. We did not see similar efforts by government in Pakistan. In the initial phase of VC industry in Israel and India, stock markets were not strong to support IPO exit, but this gap was filled by acquisition by foreign and local firms. In Pakistani scenario, both exit options are missing due to difficulties in listing of small companies and low interest in acquisition by foreign companies. Traditionally, Indian had also attitude of less risky and full control over business, but due to exposure of Indian IT and other professionals in USA, they were able to cross this barrier. In Pakistan, risk-taking and innovative thinking is still missing and one of the main factors for this is "rentseeking”. One common element of India, China and Taiwan was/is producing high number of engineering graduates. In Pakistan, we have very few engineering institutes/universities and quality of engineering graduates from these institutes is not of international repute. It was not smooth and steady growth of VC industry in these countries, but they were able to overcome the difficulties with active support of government (particularly in Israel and Taiwan case) and private sector involvement.

\section{OPPORTUNITIES FOR VC INDUSTRY IN PAKISTAN}

With GPD growth of more than 6 percent in last five years, Pakistan has been able to attract domestic as well as foreign investment. Banking sector has grown more than 30-40 percent in last 5 years and this has also attracted foreign banks to acquire local banks or start their operations in Pakistan. We have also seen around U.S \$ 12 billion foreign direct investment in Pakistan in last five years in oil and gas, banking and telecom sector. Entry of new players in mobile service provider companies has resulted in mobile connections with 55 million Pakistanis. Government of Pakistan has been successful in improving physical infrastructure, many projects are already completed and others projects are in final stage of completion. Mutual funds, asset management companies and private equity companies have also witnessed growth in last few years. This is the ideal time for venture capital industry to grow when we have many positives like business friendly government policies, government funding for sector development programs, high growth in financial sector, better standing of IT sector in local market, creation of business and technology incubators and overall economic development.

The key sectors that the venture capital firms are focusing and can focus more for attractive opportunities are telecom, IT, IT related products and services, pharmaceutical manufacturing and drug discovery/ research, bio technology, textile, retailing, renewable energy (solar and wind), entertainment (water parks, theme parks, Cineplex, hotels, restaurants, resorts), LPG, real estate/construction, Business Process Outsourcing (BPO), transportation, auto and auto parts; and light engineering products.

\section{RECOMMENDATIONS}

- Government needs to create more technology innovation centers and business incubators and create linkages of these centers with industry, financial institutions and other support services organizations.

- Banks and other financial institutions should be encouraged to invest in venture capital companies by providing tax related incentives. In the long term, this will be beneficial for banking sector in the shape of more credit requirement and other banking services.

- Government needs to launch special programs to attract Pakistani expatriates particularly working in IT related sectors of U.S and other countries to invest in technology related projects. These expatriates Pakistanis should be given incentive like easy and low cost provision of office space, better telecom infrastructure, tax incentives and other support services.

- Regulations for registration and operation of venture capital companies should be simplified, like allowing limited partnership firms for establishing venture capital firms.

- Government needs to create research and development funds for technology related sectors. $R \& D$ grants/funding can be linked with same investment by private sector.

- Government should create few sector specific venture capital funds or invest in private sector venture capital funds. In public sponsored funds, preference should be given to seed funding or financing for early-stage companies.

- One small company with qualified and experienced professionals must be established to conduct research on global venture industry (particularly India, Taiwan, Malaysia etc) and provide advisory services to new entrepreneurs in venture capital funding options. This organization can be established by partnership between government and financial sector.

- Research facilities and research culture should be strengthened in education institutes, particularly engineering universities.

- Entrepreneurship culture should be promoted among the young graduates and entrepreneurship subjects to be introduced in professional colleges and engineering universities.

- $\quad$ Listing of small and medium companies on stock exchanges to be encouraged and related legal and regulatory changes to be made to make this possible. 


\section{CONCLUSION}

The main factors for success of venture capital industry in any economy are: better physical and telecom infrastructure, easy registration and operating regulatory framework, tax incentives for VC companies as well as investors, entrepreneurship culture, availability of business and technology incubators, strong R\&D facilities, better supply of qualified and experienced human resource in IT and other technologies related sectors, mature financial sector, easy exit options and human resource to understand the dynamics of business operations and attitude of the companies. Currently, the economy of Pakistan is much better compared with 6-7 years back and there are many positive factors, which can help in growing the current infancy stage venture capital industry. There are similarities on many issues between current venture capital industry in Pakistan and venture capital industry of India in mid 1990s. This is the requirement of the time for both public and private sector to learn from the mistakes and successes of Indian venture capital industry.

Venture capital companies should also make efforts to understand the cultural attitude of Pakistani entrepreneurs and SMEs; and also the business dynamics of the country, which govern these companies. There is tendency of business secrecy and wish of control over the company among the Pakistani entrepreneurs, unlike U.S or other developed countries, where companies are built to sell for better returns. According to SMEDA survey, only 25\% SMEs have ever approached banks for lending and venture capital, is totally new phenomenon for them.

There is certainly room for venture capital because access to formal credit is linked with collateral, documentation and business history. So, new wave of young, educated entrepreneurs with different attitude will accept venture capital. Converting dreams into reality will also require political stability; better law and order situation along with direct and indirect support from government; and active involvement of private sector to timely identify right kind of opportunities.

\section{AREAS FOR FURTHER RESEARCH}

- $\quad$ To find out the awareness of VC in enterprises in Pakistan and their interest to avail this option

- To conduct the study of government sponsored VC funds in other countries, particularly India and developing countries

- To study the changing attitude and mindset among young entrepreneurs

- To study the impact of HEC grants and other public funds on R\&D, particularly in technology driven areas

\section{REFERENCES}

[1] Martin Kenney, Kyonghee Han and Shoko Tanaka: Paper on Scattering Geese: The Venture Capital Industries of East Asia, 2002.

[2] Global Insight Report, Venture Impact: The Importance of Venture Backed Companies to the US Economy, 2007.

[3] Federal Bureau of Statistics, Economic Census 2005, Karachi, 2006.

[4] State Bank of Pakistan, Annual Report 2006-07, Karachi.

[5] State Bank of Pakistan, Report on Banking System Review, 2006.

[6] Muslim Raza, Provincial Chief, SMEDA Sindh, Karachi.

[7] Sohaib Umer, Karachi, CEO TMT Ventures, March 2007.

[8] Rafiq Dossani, MartinKenney, Creating and Environment: Developing Venture Capital in India, USA, May 2001.

[9] Accessing Venture Capital in India, Stanford University: Asia/Pacific Research Center, USA, 1999.

[10] Srivastava, Saurabh, 2004, State of Venture Capital in India, Bangalore, India, 2004.

[11]Zulifqar Alam, Karachi, CFO TMT Ventures Limited, May 2007.

[12] Nadeem Ul Haq, PIDE Working Paper 2007:29 "Entrepreneurship in Pakistan”, 2007. 